\title{
Epidemiology of hypochromic anaemia in young children
}

\author{
David Stevens
}

Evidence that iron deficiency affects the developmental progress and growth of young children $^{12}$ has drawn attention to the importance of treating children who are iron deficient, even when anaemia is mild, and has given a new impetus to study the prevalence of iron deficiency in this age group. However, there are a number of reasons why it is difficult to obtain accurate estimates of the prevalence of iron deficiency anaemia in young children. Studies of the epidemiology of childhood anaemia are hampered by the problem of the definition of anaemia, by an understandable reluctance to take blood tests from apparently healthy children, and by the difficulty in assessing the contribution of the three commonest causes of anaemia: iron deficiency, genetic factors, and infection. Serum ferritin estimations are a much better test of iron status than transferrin saturation, reflect body stores of iron, ${ }^{3}$ can be performed on small amounts of blood, and are useful in clinical practice and in epidemiological studies. However serum ferritin and other tests of iron deficiency such as free erythrocyte protoporphyrin and transferrin saturation do not have well defined cut off values that exclude iron deficiency anaemia in young children, ${ }^{4}$ and all these tests can show misleading results in the presence of infection. ${ }^{56} \mathrm{~A}$ serum ferritin concentration below $10 \mu \mathrm{g} / \mathrm{l}$ is good evidence of iron deficiency, ${ }^{7}$ but some young children with serum ferritin concentrations up to $30 \mu \mathrm{g} / \mathrm{l}$ show a rise of haemoglobin in response to iron therapy. Similar problems occur with other laboratory tests of iron deficiency. ${ }^{4}$

A therapeutic trial of iron is the only completely reliable way of excluding iron deficiency anaemia and although this is relatively easy in clinical practice, it presents major problems in epidemiological studies. Genetic anaemias can be difficult to exclude because $\alpha$ thalassaemia can only be reliably diagnosed by modern DNA techniques $^{8}$ and the anaemia of infection has to be diagnosed by indirect methods. Finally, in some children all three factors may be present and contribute to the pathogenesis of anaemia.

A report from the World Health Organisation (WHO), ${ }^{9}$ using their own reference standards, ${ }^{10}$ estimates that $12 \%$ of children under 5 years of age in the developed world and $51 \%$ in the developing world are anaemic. How common is anaemia in young children in Britain and is iron deficiency mainly responsible? The WHO define anaemia in this age group as a haemoglobin concentration below $110 \mathrm{~g} / \mathrm{l}^{10}$ which is approximately $2 \mathrm{SD}$ below the mean for iron replete white children of this age group. ${ }^{11}$ The reference range is therefore suitable for a healthy iron replete population with a very low frequency of genetic anaemia. It is important to recognise that some children with iron deficiency anaemia have haemoglobin concentrations above $110 \mathrm{~g} / 1^{12}$ and show a rise of haemoglobin with iron therapy to achieve their optimal haemoglobin and that some children with concentrations below $110 \mathrm{~g} / 1$ are healthy and have no pathological cause for a low haemoglobin level. Despite these reservations the WHO definition is a good starting point to examine the prevalence and cause of anaemia in this group in Britain.

\section{Iron deficiency}

The prevalence of iron deficiency anaemia has decreased appreciably in young British children since Helen McKay's classic studies in central London in the $1920 \mathrm{~s}^{13}$ Very few of the infants between 2 and 17 months of age in her study achieved a haemoglobin concentration of $110 \mathrm{~g} / 1$ without iron supplements. This contrasts with 1971, when Burman reported that during the first two years of life the mean haemoglobin of Bristol infants who were not given iron supplements was similar to that of infants who were given iron in Mackay's study. ${ }^{14}$ However iron deficiency anaemia remains common in inner city areas (table 1) where in one study Aukett et al found that $27 \%$ of Asian and $18 \%$ of European children had haemoglobin concentrations below $110 \mathrm{~g} / 1 .{ }^{2}$ Serum ferritin estimations and response to iron therapy showed that most of this anaemia was due to iron deficiency. Grindulis et al also found that anaemia was common in young Asian children and that $90 \%$ of those with haemoglobin concentrations below $100 \mathrm{~g} / \mathrm{l}$ had serum ferritin below $7 \mu \mathrm{g} / \mathrm{l}^{16}$ Earley et al found that anaemia was commoner in Asian than European children but, surprisingly, low serum ferritin concentrations were commoner in the latter (personal communication). ${ }^{17}$ However, serum ferritin proved to be an unreliable test of iron deficiency in this study. Burman's study ${ }^{14}$ contained many middle class infants but recent studies including more affluent groups are scanty. Wright et al found that there was no significant difference in the proportion of affluent and deprived infants with haemoglobin concentrations below $110 \mathrm{~g} / \mathrm{l}$ and remarked that the red cell indices were only
Gloucestershire

Gloucester GL1 3NN

Correspondence to:

Dr Stevens. 
Table 1 Surveys of anaemia in young children

\begin{tabular}{|c|c|c|c|c|c|}
\hline Author & $\begin{array}{l}\text { Location } \\
\text { of study }\end{array}$ & $\begin{array}{l}\text { Age } \\
\text { (months) }\end{array}$ & Ethnic group & $\begin{array}{l}\text { Anaemic* } \\
(\%)\end{array}$ & $\begin{array}{l}\text { Low serum } \\
\text { ferritin (\%) }\end{array}$ \\
\hline Ehrhardt ${ }^{15}$ & Bradford & $6-48$ & $\begin{array}{l}\text { European } \\
\text { Asian }\end{array}$ & $\begin{array}{l}12 \\
28\end{array}$ & $\begin{array}{l}28 t \\
45 t\end{array}$ \\
\hline Grindulis $e t a l^{16}$ & Birmingham & $21-23$ & Asian & 31 & $57 \ddagger$ \\
\hline Aukett et $a l^{2}$ & Birmingham & $17-19$ & $\begin{array}{l}\text { European } \\
\text { Asian }\end{array}$ & $\begin{array}{l}18 \\
27\end{array}$ & $47 \S$ \\
\hline Earley et $a l^{17}$ & London & $6-72$ & $\begin{array}{l}\text { European } \\
\text { Asian }\end{array}$ & $\begin{array}{l}10 \\
27\end{array}$ & $\begin{array}{l}35 t \\
13 t\end{array}$ \\
\hline Mills $^{18}$ & London & $8-24$ & $\begin{array}{l}\text { European } \\
\text { Asian } \\
\text { Predominantly } \\
\text { Caribbean }\end{array}$ & $\begin{array}{l}17 \\
26 \\
18\end{array}$ & $\mathbf{n k \|}$ \\
\hline Marder et $a l^{19}$ & Nottingham & $15-24$ & $\begin{array}{l}\text { European } \\
\text { Asian } \\
\text { Caribbean }\end{array}$ & $\begin{array}{l}16 \\
26 \\
20\end{array}$ & nk\| \\
\hline Wright et $a l^{20}$ & Newcastle & $9-15$ & $\begin{array}{l}\text { 'Affluent' } \\
\text { 'Deprived' }\end{array}$ & $\begin{array}{l}11 \\
16\end{array}$ & nk\| \\
\hline James $e t a l^{21}$ & Bristol & $12-48$ & $\begin{array}{l}\text { European } \\
\text { Caribbean } \\
\text { Indian } \\
\text { Vietnamese }\end{array}$ & $\left.\begin{array}{r}4 \pi \\
8 \pi \\
17 \pi \\
20 \pi\end{array}\right\}$ & $\begin{array}{l}\text { Limited } \\
\text { number } \\
\text { of estimations }\end{array}$ \\
\hline
\end{tabular}

${ }^{*}$ Haemoglobin concentration $<110 \mathrm{~g} / \mathrm{l}$ (exceptions indicated by I)

†Percentage of total sample with serum ferritin concentration $<10 \mu \mathrm{g} /$; $\ddagger$ serum ferritin concentration $<7 \mu \mathrm{g} / \mathrm{l}$.

Percentage of anaemic children with serum ferritin concentration $<7 \mu \mathrm{g} / \mathrm{l}$.

No biochemical tests of iron deficiency performed.

\Haemoglobin concentration $<105 \mathrm{~g} / \mathrm{l}$.

typical of iron deficiency anaemia in $3 \% .^{20}$ The evidence suggests, however, that the prevalence of iron deficiency anaemia in young British children varies greatly according to social circumstances and nutritional habits but is unlikely to be less than $2-3 \%$ in any group and has been shown to be approaching $30 \%$ in the most disadvantaged.

The possibility of coeliac disease and occult blood loss must be considered in children with iron deficiency anaemia, particularly if the anaemia is recurrent, but the great majority of cases of iron deficiency anaemia in young children are due to a failure of nutritional iron to keep up with the demands of growth. Normal birthweight infants are born with sufficient body iron, mainly in the form of haemoglobin, to keep up with the demands of growth irrespective of their nutritional intake until about 4-6 months of age. ${ }^{22}$ Low birthweight infants, however, are at risk of developing iron deficiency anaemia by 2 months of age if they are not given iron supplements. ${ }^{23}$ After 4 to 6 months of age a number of nutritional factors may predispose the infant to developing iron deficiency. ${ }^{7}$ Delayed introduction of solid feeds, feeds of low iron content or with poorly available iron, or feeds which inhibit iron absorption, ${ }^{7}$ and ingestion of unmodified cows' milk $^{24}{ }^{25}$ may all contribute. However, the relative importance of these factors in the pathogenesis of iron deficiency in young British children is not known.

\section{Infection}

Common infections such as otitis media and upper respiratory tract infection can depress haemoglobin concentrations in young children. ${ }^{26}$ Even the mild infection produced by the attenuated measles vaccine can reduce haemoglobin in children. ${ }^{27}$ As iron deficiency becomes less common in affluent societies infection will probably account for an increasing proportion of cases of mild anaemia in young children. ${ }^{526}$ Repeated infections increase the severity of the anaemia and low haemoglobin concentrations can persist for one month after infections even in children who subsequently show no signs of illness. ${ }^{5}$ In paediatric practice, persistent or repeated infections are a common reason why young children have a haemoglobin measured and are at the same time probably a much commoner cause of anaemia than was previously recognised.

\section{Genetic factors}

Sickle cell anaemia, thalassaemia, and glucose6-phosphate dehydrogenase deficiency are all important causes of anaemia in racial groups originating from malarial areas and are therefore important in children of many of the ethnic minorities in Britain. Haemoglobin $\mathrm{E}$ is very common in some parts of South East Asia and also occurs in India. ${ }^{28}$ Heterozygotes have normal haemoglobin concentrations with some microcytosis and hypochromia and homozygotes are not usually anaemic but the condition may interact with $\beta$ thalassaemia to cause severe anaemia. ${ }^{28}$ Mild forms of thalassaemia such as $\beta$ thalassaemia trait and mild forms of $\alpha$ thalassaemia can both cause a hypochromic microcytic anaemia, are very common in some racial groups, and can easily be confused with iron deficiency anaemia. Heterozygotes for $\beta$ thalassaemia have a mild asymptomatic hypochromic anaemia, the severity of which probably depends mainly on whether the affected person inherits the $\beta^{\prime \prime}$ or $\beta^{+}$type of $\beta$ thalassaemia. ${ }^{29}$ In a study of young children aged 1-3 years, heterozygous for $\beta$ thalassaemia of unspecified type, $90 \%$ had haemoglobin concentrations between 90 and $106 \mathrm{~g} / 1 .{ }^{30}$ The proportion of carriers in different ethnic groups is difficult to determine from published work because the populations studied are in many cases small, there may be great variation within ethnic groups, and the diagnostic criteria also vary. The results of some studies are shown in table 2 but should not be regarded as comprehensive. The Indian subcontinent is genetically ex- 


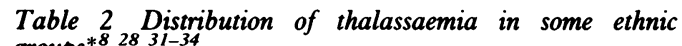
groups*8 $28 \quad 31-34$

\begin{tabular}{lcl}
\hline Ethnic group & $\begin{array}{l}\beta \text { Thalassaemia } \\
(\text { carriers) }\end{array}$ & $\begin{array}{l}\alpha \text { Thalassaemia } \\
\text { (frequency of }-\alpha)\end{array}$ \\
\hline Afro-Caribbean & $0.8 \%$ & 0.18 \\
Indian & $<1-\sim 20 \%$ & $0.05-0.9$ \\
Mediterranean & $<1-\sim 20 \%$ & $0.04-0.18$ \\
\hline
\end{tabular}

${ }^{*}$ See text.

tremely heterogeneous and even within relatively small geographical areas the frequency of haemoglobinopathies can vary widely between different tribes, castes, and religious groups. ${ }^{32}$

$\alpha$ Thalassaemia results from reduction of $\alpha$ globin synthesis, either from a deletion of one or more of the four genes $(\alpha \alpha / \alpha \alpha)$ which are responsible for $\alpha$ globin production, or as a result of 'non-deletional' abnormalities, which through a variety of mechanisms reduce $\alpha$ globin synthesis without gene deletion. ${ }^{33}$ Severe forms of $\alpha$ thalassaemia, such as the double gene deletion variety $(--/)$ and severe nondeletional forms are uncommon in the main ethnic minorities in Britain, which explains why the clinically significant forms of $\alpha$ thalassaemia, Bart's hydrops and haemoglobin $\mathrm{H}$ disease, are rarely seen. However the single $\alpha$ gene defect $(-\alpha)$ is common in many parts of the world which have provided immigrants to British including the Caribbean, South East Asia, the Middle East, Indian subcontinent, and some Mediterranean countries. ${ }^{33}$ Table 2 shows the frequency of the single $\alpha$ gene defect $(-\alpha)$ in some ethnic groups. The frequency is extremely high in many of these groups resulting in very high percentages of the population having the defect. For example, from a frequency of 0.18 in Afro-Caribbeans it can be estimated that $33 \%$ have the defect (heterozygotes and homozygotes). At the present time accurate estimates of the frequency of $\alpha$ thalassaemia, based on DNA studies, are not yet available for the main immigrant groups from the Indian subcontinent.

Is $\alpha$ thalassaemia a common cause of hypochromic anaemia in children in the ethnic minorities in Britain? Although DNA studies indicate that the single $\alpha$ gene defect is likely to be present in thousands of children in the ethnic minorities, the effect on the overall prevalence of hypochromic anaemia may be quite limited. The single $\alpha$ gene defect is a very mild disorder. Homozygotes have a mild hypochromic anaemia and many of the heterozygotes have normal red cell indices. ${ }^{33}{ }^{34}$ Young Jamaican children, heterozygous for the single $\alpha$ gene defect, were found to have lower mean haemoglobin, mean corpuscular volume, and mean corpuscular haemoglobin than normal children but there was considerable overlap with normal children. ${ }^{35}$ Epidemiological studies using modern DNA techniques have provided evidence that $\alpha$ thalassaemia of the single $\alpha$ gene defect type is a common cause of hypochromic anaemia in the Pacific islands of Vanuatu. ${ }^{36} \mathrm{It}$ may be responsible for much of the mild hypochromic anaemia previously thought to be due to iron deficiency in Bedouin infants in
Saudi Arabia, ${ }^{37}$ and is an important cause of microcytosis in Gujerati children in London. ${ }^{17}$ In the latter study suspected iron deficiency was confirmed by therapeutic trial of iron, ${ }^{17}$ but in the others the less reliable method of serum ferritin estimations was used. ${ }^{36} 37$ The effect of iron deficiency may therefore have been underestimated. In clinical practice the single $\alpha$ gene form of $\alpha$ thalassaemia is probably an important cause of mild hypochromic anaemia and microcytosis persisting after iron therapy in children from the ethnic minorities.

\section{Conclusion}

It is clear that many young British children have haemoglobin concentrations which are low by WHO reference standards. Although other causes of hypochromic anaemia such as lead poisoning and renal failure are important to exclude if clinically indicated, iron deficiency, infection, and thalassaemia ${ }^{26}$ are responsible for the vast majority of cases of mild anaemia (haemoglobin 100-110 g/l) in young children. All three types of anaemia can result in a hypochromic blood picture, although infection is more often associated with normochromic red cells. Iron deficiency, a preventable nutritional disorder, is still common in disadvantaged groups but the overall prevalence is unknown. Young Asian children living in inner city areas have the highest risk of developing iron deficiency anaemia but no ethnic group or social class is immune from this disorder. Dietary campaigns $^{3839}$ have had success in preventing iron deficiency but more studies are needed to find out the best way to improve the diet of young children in order to prevent this condition, which is probably more harmful than we previously realised.

In clinical practice it is important to treat iron deficiency anaemia in young children. Clinical history, including that of recent infections, a few questions about the diet, and examination of the child and his blood film and/or red cell indices often leads to the correct diagnosis, but if there is any doubt a therapeutic trial of iron should be given and accompanied by dietary advice. This is very unlikely to cause harm even if the anaemia is due to a recent infection or thalassaemia trait. It is probably best to investigate for thalassaemia trait after iron deficiency has been corrected. Children whose haemoglobin concentration and red cell indices do not return to normal after a course of iron require investigation. Poor compliance, a persisting cause of iron deficiency, and other causes of anaemia should be considered. Children from the ethnic minorities who do not fully respond to iron should have haemoglobin electrophoresis performed, including haemoglobin $\left(\mathrm{HbA}_{2}\right)$ estimation to diagnose heterozygous $\beta$ thalassaemia. If this is excluded and the child does not have any other cause of anaemia, and the serum ferritin concentration is normal, the most likely cause of mild persistent hypochromic anaemia and microcytosis is a mild form of $\alpha$ thalassaemia. Prolonged or repeated courses of iron should be avoided if the anaemia is due to thalassaemia. 
I thank Dr D R Higgs and Professor B A Wharton for reading through this manuscript and making helpful suggestions.

1 Oski FA, Honig AS, Helm B, Howanitz P. Effect of iron therapy on behaviour performance in nonanemic iron deficient infants. Pediatrics 1983;71:877-80.

2 Aukett MA, Parks YA, Scott PH, Wharton BA. Treatmen with iron increases weight gain and psychomotor development. Arch Dis Child 1986;61:849-59.

3 Jacobs A, Miller F, Wormwood M, Beamish MR, Waldrop CA. Ferritin in normal subjects and patients with iron deficiency and iron overload. BMF 1972;iv:206-8.

4 Dallman PR, Reeves JD, Driggers DA, Lo EYT. Diagnosis of iron deficiency: the limitations of laboratory tests in predicting response to treatment in year-old infants. f Pediatr 1981;98:376-81.

5 Jansson LT, Kling S, Dallman PR. Anemia in children with acute infections seen in a primary care pediatric outpatient acute infections seen in a primary care pedic
clinic. Pediatr Infect Dis 1986;5:424-7.

6 Elin RJ, Wolff SM, Finch CA. Effect of fever on serum iron and ferritin concentrates in man. Blood 1977;49:147-53.

7 Oski FA, Stockman JA. Anemia due to inadequate iron sources or poor iron utilisation. Pediatr Clin North Am 1980;27:237-52.

8 Weatherall DJ, Clegg JB. The thalassaemia syndromes. 3rd Ed. Oxford: Blackwell, 198

9 De Maeyer E, Adiels-Tegman M. The prevalence of anaemia in the world. World Health Stat $Q$ 1985;38:302-16.

10 World Health Organisation. Nutritional anaemias. WHO Tech Rep Ser 1972; No 503.

11 Dallman PR, Siimes MA. Percentile curves for hemoglobin and red cell volume in infancy and childhood. 7 Pediatr 1979;94:26-31.

12 Driggers DA, Reeves JD, Lo EYT, Dallman PR. Iron deficiency in one-year-old infants: comparison of results of a therapeutic trial in infants hemoglobin. $\mathcal{f}$ Pediatr 1981;98:753-8.

13 MacKay HM. Anaemia in infancy: its prevalence and prevention. Arch Dis Child 1928;3:117-47.

14 Burman D. Haemoglobin levels in normal infants aged 3 to 24 months, and the effect of iron. Arch Dis Child 1972;47: 261-71.

15 Ehrhardt $P$. Iron deficiency in young Bradford children from different ethnic groups. $B M F$ 1986;292:90-3.

16 Grindulis H, Scott PH, Belton NR, Wharton BA. Combined deficiency of iron and vitamin $\mathrm{D}$ in Asian toddlers. Arch Dis Child 1986;61:843-8.

17 Earley A, Valman HB, Altman DG, Pippard MJ. Microcytosis, iron deficiency, and thalassaemia in preschool children. Arch Dis Child 1990;65:610-4.

18 Mills AF. Surveillance for anaemia: risk factors in patterns of milk intake. Arch Dis Child 1990;65:428-31.

19 Marder A, Nicoll A, Polnay L, Shulman CE. Discovering anaemia at child health clinics. Arch Dis Child 1990;65: 892-4.

20 Wright CM, Reading RF, Halse PC, Watson JG. Iron deficiency in adolescents. $B M \mathcal{F} 1989 ; 298: 1035-6$.
21 James J, Evans J, Male P, Pallister C, Hendrikz JK, Oakhill A. Iron deficiency in inner city pre-school children: development of a general practice screening programme. development of a general practice scre

22 Oski FA. Food for the red cell. In: Wharton BA, ed. Nutrition in childhood. Topics in paediatrics 2. Royal College of Physicians of London: Pitman Medical, 1980:132-50.

23 Lundstrom U, Siimes MA, Dallman PR. At what age does iron supplementation become necessary in low birth weight infants? f Pediatr 1977;91:878-83.

24 Tunnessen WW, Oski FA. Consequences of starting whole cow milk at 6 months of age. 7 Pediatr 1987;111:813-6.

25 Zeigler EE, Fomon SI, Nelson SE, et al. Cow milk feeding in infancy: further observations on blood loss from the gastrointestinal tract. $\mathcal{F}$ Pediatr 1990;116:11-8.

26 Dallman PR. Changing characteristics of childhood anemia. 7 Pediatr 1989;114:161-4.

27 Olivares $M$, Walter T, Osorio M, Chahud P, Schleshinger L. Anemia of mild viral infection: the measles vaccine as a model. Pediatrics 1990;84:851-8.

28 Dacie JV. The haemolytic anaemias. Vol 1. The hereditary haemolytic anaemias. Part 2. 3rd Ed. London: Churchill Livingstone, 1988

29 Millard DP, Mason K, Serjeant BE, Serjeant GR. Comparison of haematological features of the $\beta^{\circ}$ and $\beta^{+}$thalassaemia traits in Jamaican negroes. Br $\mathcal{F}$ Haematol 1977;36:161-70.

30 Berman BW, Ritchey AK, Jekel JF, Schwartz AD, Guillioti DK, Pearson HA. Hematology of $\beta$-thalassaemia trait-age related developmental aspects and intrafamilial correlations. I Pediatr 1980;97:901-5.

31 Serieant GR, Serieant BE, Forbes M, Hayes RJ, Higgs DR Lehmann $H$. Haemoglobin gene frequencies in the Jamaican population: a study of 100,000 newborns. $B$ f Haematol 1986;64:253-62.

32 Brittenham GM. The geographic and ethnographic distribution of hemoglobinopathies in India. In: Bowman JE, ed. Distribution and evolution of hemoglobin and globin loci. Amsterdam: Elsevier Publishing Co, 1983:171-8.

33 Higgs DR, Vickers MA, Wilkie AOM, Pretorius IM, Jarman AP, Weatherall DJ. A review of the molecular genetics of the human (z-globin gene cluster. Blood 1988;73:1081-104.

34 the human (x-globin gene cluster. Blood 1988;73:1081-104. Topics in Hematology 1983;4:37-97.

35 Maude GH, Higgs DR, Beckford M, et al. Alpha thalassaemia and the haematology of normal Jamaican children. Clin mia and the haematology of no

36 Bowden DK, Hill AVS, Higgs DR, Weatherall DJ, Clegg JB. Relative roles of genetic factors, dietary deficiency, and infection in anaemia in Vanuatu, South West Pacific Lancet 1985; ii: 1025-8.

37 Stevens DW, Wainscoat JS, Ketley N, Timms P, Ayoub D Shah $\mathbf{R}$. The pathogenesis of hypochromic anaemia in Saudi infants. $\mathcal{F}$ Trop Pediatr 1989;35:301-5.

38 Miller V, Swaney S, Deinard A. Impact of the WIC program on the iron status of infants. Pediatrics 1985;75:100-5.

39 James J, Lawson P, Male P, Oakhill A. Preventing iron deficiency in preschool children by implementing an educational and screening programme in an inner city practice. BMF 1989;299:838-40. 